\title{
Relating in vitro neutralisation level and protection in the CVnCoV (CUREVAC) trial.
}

Deborah Cromer ${ }^{1}$, Arnold Reynaldi ${ }^{1}$, Megan Steain ${ }^{2,3}$, James A Triccas ${ }^{2,3}$, Miles P Davenport $^{1 \#}$. David S Khoury ${ }^{1 \#}$

1. Kirby Institute, University of New South Wales, Sydney, Australia

2. School of Medical Sciences, Faculty of Medicine and Health, The University of Sydney, Sydney, New South Wales, Australia.

3. Sydney Institute of Infectious Diseases and Charles Perkins Centre, The University of Sydney, Sydney, New South Wales, Australia.

\# Corresponding author: m.davenport@unsw.edu.au; dkhoury@kirby.unsw.edu.au 
medRxiv preprint doi: https://doi.org/10.1101/2021.06.29.21259504; this version posted June 30, 2021. The copyright holder for this preprint (which was not certified by peer review) is the author/funder, who has granted medRxiv a license to display the preprint in perpetuity.

\begin{abstract}
:
A recent study analysed the relationship between neutralising antibody response and protection from SARS-CoV-2 infection across eight vaccine platforms ${ }^{1}$. The efficacy results from a phase $2 b / 3$ trial of a ninth vaccine candidate, CVnCoV (CUREVAC), was announced on 16 June $2021^{2}$. The low efficacy of this new mRNA vaccine, which showed only $47 \%$ protection from symptomatic SARS-CoV-2 infection, was surprising given the high efficacy of two previous mRNA-based vaccines ${ }^{3,4}$. A number of factors have been suggested to play a role in the low efficacy in the CVnCoV study, particularly around the dose and immunogenicity of the vaccine (which uses an unmodified mRNA construct ${ }^{5,6}$ ) and the potential role of infection with SARS-CoV-2 variants (which were the dominant strains observed in the CVnCoV trial)2.
\end{abstract}

\title{
Main text:
}

To investigate the potential effects of dose and immunogenicity in the CVnCoV construct we extracted data on in vitro neutralisation titre for three reported mRNA vaccines, $\mathrm{CVnCoV}^{6}$, mRNA-12737, and BNT162 $\mathrm{b}^{8}$. To allow comparison of neutralisation levels between studies we normalised to the average convalescent titre in the same study (recognising that convalescent groups were not standardised between studies). Figure 1a compares dose and neutralisation levels across the 3 vaccines and suggests that the lower neutralisation in the CVnCoV study is consistent with the neutralisation observed when lower doses of mRNA$1273^{7}$, and BNT162 b2 ${ }^{8}$ were administered.

Another factor suggested to affect the observed vaccine efficacy was the circulating SARSCoV-2 variant viruses encountered during the $\mathrm{CVnCoV}$ trial. In the primary phase 3 studies used for licensure of the other eight vaccines, the ancestral virus (which matches the spike protein used as the vaccine immunogen) was the dominant strain in circulation ${ }^{1}$. However, more recent non-randomised studies have suggested a reduced efficacy of some of these vaccines against SARS-CoV2 variants ${ }^{9}$. In vitro studies have shown that many SARS-CoV-2 variants show a significant reduction in neutralisation titre compared to the ancestral virus, and that this effect is observed using serum from both convalescent and vaccinated subjects ${ }^{10,11}$. In the CVnCoV phase 3 trial the infecting virus was composed almost entirely of a variety of circulating SARS-CoV-2 variants. For example, the alpha (B.1.1.7) variant 
medRxiv preprint doi: https://doi.org/10.1101/2021.06.29.21259504; this version posted June 30, 2021. The copyright holder for this preprint (which was not certified by peer review) is the author/funder, who has granted medRxiv a license to display the preprint in perpetuity.

All rights reserved. No reuse allowed without permission.

represented about $41 \%$ of infections in the $\mathrm{CVnCoV}$ trial and has been shown by others to have a 2.3-fold drop in neutralising titre compared to the ancestral virus for another mRNA vaccine ${ }^{10}$. Similarly, the beta (B.1.351), gamma (P.1) and delta (B.1.617.2) variants have been shown to have a 5.8, 3.2-fold and 6.3-fold drop in neutralising titre respectively ${ }^{10,11}$.

To visualise the potential effects of reduced neutralising level on vaccine efficacy, Figure $1 \mathrm{~b}$ plots the in vitro neutralising titre (normalised to the mean convalescent sera) against the ancestral virus observed in the CVnCoV phase $1 / 2$ study $^{6}$ along with the observed efficacy in the Phase 3 trial. It also shows the predicted effects of the drop in neutralisation titre for the different variants listed above ${ }^{10,11}$. The observed efficacy against variants appears consistent with the initial level of neutralisation against the ancestral virus and the expected drop in neutralisation titre to variants (as reported for other mRNA vaccines).

This analysis suggests that both a lower dose than the other mRNA vaccines (Fig 1a), as well as the effects of SARS-CoV-2 variants in reducing the neutralising ability of vaccine-induced serological responses (Fig 1b) were significant contributors to the low efficacy observed in the CVnCoV study. 
medRxiv preprint doi: https://doi.org/10.1101/2021.06.29.21259504; this version posted June 30, 2021. The copyright holder for this preprint (which was not certified by peer review) is the author/funder, who has granted medRxiv a license to display the preprint in perpetuity.

All rights reserved. No reuse allowed without permission.

\section{Ethics statement:}

This work was approved under the UNSW Sydney Human Research Ethics Committee (approval HC200242).

\section{Funding statement:}

This work is supported by an Australian government Medical Research Future Fund awards GNT2002073, MRF2005544,MRF2005760 (to MPD) and MRF2007221 (JAT, MS), an NHMRC program grant GNT1149990 (MPD), and NHMRC CRE 1153493 (JAT). DSK, DC and MPD are supported by NHMRC Fellowship / Investigator grants.

\section{Competing Interests statement:}

The authors declare no competing interests.

\section{Authorship Statement:}

All authors contributed to the data collection, design of the study, writing of the manuscript and revision of the manuscript. DSK, DC, AR, and MPD contributed to the modelling and statistical analysis of the data.

\section{Data Availability Statement:}

All data and code are freely available from the corresponding author upon request.

\section{Acknowledgments:}

The authors wish to thank Sarah Sasson for helpful comments and careful reading of the manuscript. 
medRxiv preprint doi: https://doi.org/10.1101/2021.06.29.21259504; this version posted June 30, 2021. The copyright holder for this preprint (which was not certified by peer review) is the author/funder, who has granted medRxiv a license to display the preprint in perpetuity.

All rights reserved. No reuse allowed without permission.

\section{Figure legends:}

Figure 1:

Potency, immunogenicity, and protection from SARS-CoV-2 infection. (a) The relationship between immunisation dose ( $x$-axis) and in vitro neutralisation titre (expressed as a foldchange over convalescent serum in the same study)(y-axis) is shown for three mRNA-based vaccines, $\mathrm{CVnCoV}^{6}, \mathrm{mRNA}-1273^{7}$, and $\mathrm{BNT} 162 \mathrm{~b} 2^{8}$. The neutralisation level of the $12 \mu \mathrm{g}$ dose of CVnCoV was not significantly different from that of the $10 \mu \mathrm{g}$ BNT162b2 dose $(p=0.11, t-$ test). (b) The previously reported relationship between neutralisation level (normalised to the mean convalescent titre in the same study) and protection from symptomatic SARSCoV-2 infection is shown in red ${ }^{1}$. The observed mean neutralisation level against ancestral SARS-CoV-2 virus in vitro (grey) ${ }^{6}$, as well as the predicted drop in neutralisation level (indicated by arrow and coloured dots and whiskers) against the alpha, beta, delta and gamma variants ${ }^{10,11}$ are plotted against the protective efficacy observed in the CVnCoV trial $^{2}$. 
medRxiv preprint doi: https://doi.org/10.1101/2021.06.29.21259504; this version posted June 30, 2021. The copyright holder for this preprint (which was not certified by peer review) is the author/funder, who has granted medRxiv a license to display the preprint in perpetuity.

\section{References}

1. Khoury, D.S., et al. Neutralizing antibody levels are highly predictive of immune protection from symptomatic SARS-CoV-2 infection. Nature Medicine (2021).

2. CureVac. CureVac Provides Update on Phase 2b_3 Trial of First-Generation COVID-19 Vaccine Candidate, CVnCoV - CureVac. (2021).

3. Baden, L.R., et al. Efficacy and Safety of the mRNA-1273 SARS-CoV-2 Vaccine. $N$ Engl J Med 384, 403-416 (2020).

4. Polack, F.P., et al. Safety and Efficacy of the BNT162b2 mRNA Covid-19 Vaccine. $N$ Engl J Med 383, 2603-2615 (2020).

5. Kariko, K., Buckstein, M., Ni, H. \& Weissman, D. Suppression of RNA recognition by Toll-like receptors: the impact of nucleoside modification and the evolutionary origin of RNA. Immunity 23, 165-175 (2005).

6. Kremsner, P., et al. Phase 1 Assessment of the Safety and Immunogenicity of an mRNA- Lipid Nanoparticle Vaccine Candidate Against SARS-CoV-2 in Human Volunteers. medRxiv, 2020.2011.2009.20228551 (2020).

7. Jackson, L.A., et al. An mRNA Vaccine against SARS-CoV-2 - Preliminary Report. $N$ Engl J Med 383, 1920-1931 (2020).

8. Walsh, E.E., et al. Safety and Immunogenicity of Two RNA-Based Covid-19 Vaccine Candidates. New England Journal of Medicine 383, 2439-2450 (2020).

9. Abu-Raddad, L.J., Chemaitelly, H. \& Butt, A.A. Effectiveness of the BNT162b2 Covid19 Vaccine against the B.1.1.7 and B.1.351 Variants. New England Journal of Medicine (2021).

10. Wall, E.C., et al. Neutralising antibody activity against SARS-CoV-2 VOCs B.1.617.2 and B.1.351 by BNT162b2 vaccination. The Lancet (2021).

11. Wang, P., et al. Increased resistance of SARS-CoV-2 variant P.1 to antibody neutralization. Cell Host \& Microbe 29, 747-751.e744 (2021). 

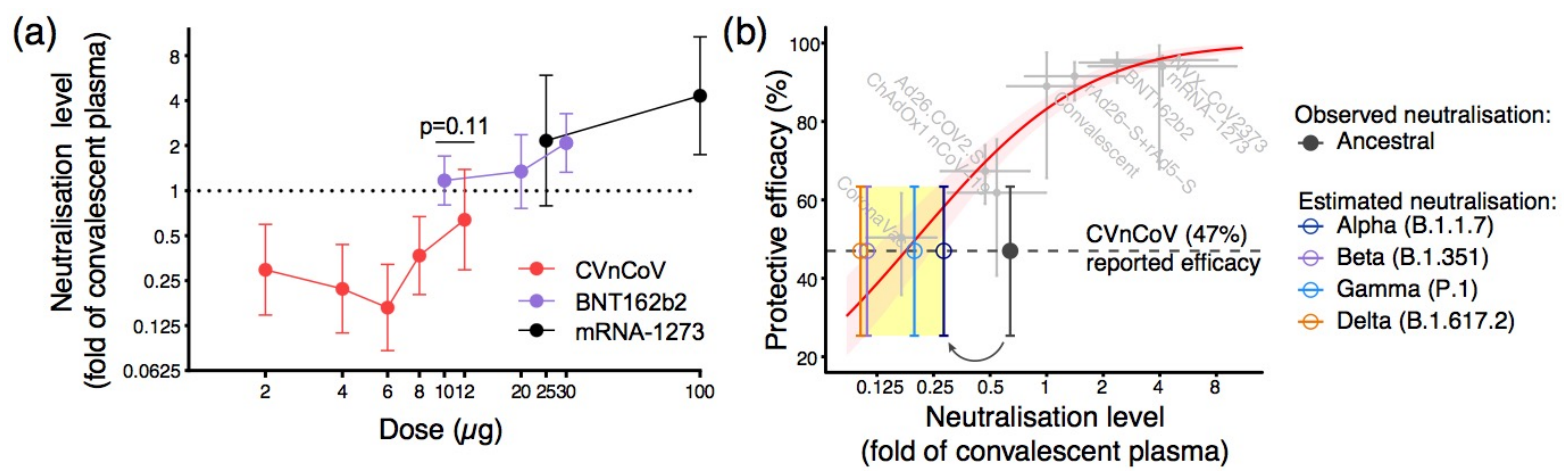

\section{Figure 1:}

Potency, immunogenicity, and protection from SARS-CoV-2 infection. (a) The relationship between immunisation dose ( $x$-axis) and in vitro neutralisation titre (expressed as a foldchange over convalescent serum in the same study)(y-axis) is shown for three mRNA-based

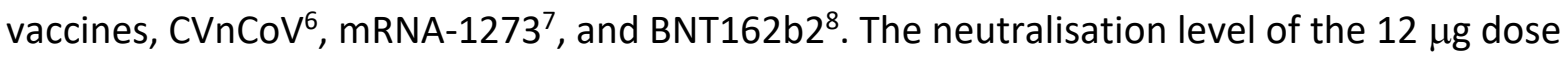
of CVnCoV was not significantly different from that of the $10 \mu \mathrm{g}$ BNT162b2 dose ( $\mathrm{p}=0.11$, ttest). (b) The previously reported relationship between neutralisation level (normalised to the mean convalescent titre in the same study) and protection from symptomatic SARSCoV-2 infection is shown in red $^{1}$. The observed mean neutralisation level against ancestral SARS-CoV-2 virus in vitro (grey) ${ }^{6}$, as well as the predicted drop in neutralisation level (indicated by arrow and coloured dots and whiskers) against the alpha, beta, delta and gamma variants ${ }^{10,11}$ are plotted against the protective efficacy observed in the CVnCoV trial $^{2}$. 